\title{
PERAN PENDIDIKAN KEWARGANEGARAAN DALAM PEMBENTUKAN KARAKTER PADA ANAK GENERASI MILENIAL
}

\author{
Yuga Fibra Nurhakim, Dinie Anggraeni Dewi \\ Universitas Pendidikan Indonesia Kampus Daerah Cibiru Program Studi Pendidikan Guru Sekolah dasar \\ Email: : yugafibraanh@upi.edu,dinieanggraenidewi@upi.edu,
}

\begin{abstract}
Abstact
This research aims to describe the important role of Civic Education in character building for children of the millennial generation. In this research, the method used is literature research.To obtain the data from existing books, journals, theses, literature, and others related to the problem to be studied. The results of this research are that it turns out that the role of Civic Education in character building for millennial generation children is very important for life because Civic Education is not only a subject but is used as a benchmark for living everyday life, because it contains values and norms, legal rules, and Pancasila values. Civic Education must continue to exist in schools and colleges because otherwise it will have an impact on character building in children, especially for the millennial generation who will become the nation's future successors. This millennial generation will also be an example for their children and grandchildren.
\end{abstract}

Key words: : Civic Education, Character, Millennial Generation 


\begin{abstract}
Abstrak
Penelitian ini bertujuan untuk memberi gambaran tentang pentingnya peran Pendidikan Kewarganegaraan dalam pembentukan karakter pada anak generasi milenial. Pada penelitian ini, metode yang digunakan adalah studi pustaka. Untuk memperoleh datanya itu dari buku-buku yang sudah ada, jurnal, tesis, literatur, dan lainlain yang berhubungan dengan masalah yang akan diteliti. Hasil dari penelitian ini adalah bahwa ternyata peran pendidikan kewarganegaraan dalam pembentukan karakter pada anak generasi milenial itu sangatlah berperan bagi kehidupan karena pendidikan kewarganegaraan ini tak hanya sebagai mata pelajaran saja tetapi dijadikan sebagai patokan untuk menjalani kehidupan sehari-hari, karena didalamnya itu terdapat nilai dan norma, aturan hukum, dan nilai-nilai pancasila. Pendidikan Kewarganegaraan ini haruslah terus ada di sekolah-sekolah dan di perguruan tinggi karena jika tidak hal itu akan berdampak pada pembentukan karakter pada anak terutama untuk generasi milenial yang akan menjadi penerus bangsa di masa depan. Generasi milenial ini juga akan menjadi teladan untuk anak dan cucunya.
\end{abstract}

\title{
Kata kunci: Pendidikan Kewarganegaraan, Karakter, Generasi Milenial
}




\section{PENDAHULUAN}

Pendidikan di Indonesia sekarang ini belum mendapatkan hasil yang baik. Terutama dalam hal pembentukan karakter, khususnya karakter pada anak. Karakter merupakan sesuatu hal yang sangat penting bagi kehidupan terutama untuk anak karena tanpa adanya karakter yang baik anak itu akan terjerumus ke hal-hal yang tidak diinginkan. Pendidikan karakter pada masa ini mengalami banyak masalah yang muncul Pendidikan karakter di nilai sangat penting untuk di mulai pada anak usia dini karena pendidikan karakter adalah proses pendidikan yang ditujukan untuk mengembangkan nilai, sikap, dan perilaku yang memancarkan akhlak mulia atau budi pekerti luhur.Dalam membentuk perlu dilakukan sejak anak tersebut masih usia dini karena pada masa mulailah tumbuh karakter pada anak tersebut. Karakter itu sebenarnya ada pada saat anak itu belum dilahirkan, tetapi karakter tersebut harus terus-menerus diajarkan melalui sosialisasi dan pendidikan sejak usia dini. Usia dini merupakan masa kritis bagi pembentukan karakter seseorang.

Banyak pakar mengatakan bahwa kegagalan penanaman karakter sejak usia dini, akan membentuk pribadi yang bermasalah dimasa dewasanya kelak. Selain itu, menanamkan moral kepada generasi muda adalah usaha yang optimal. Oleh karena itu, penanaman moral melalui pendidikan karakter sedini mungkin kepada anak-anak adalah kunci utama untuk membangun bangsa. Pendidikan di sekolah merupakan salah satu wadah dalam menunjang pembentukan karakter tiap individu. Di setiap sekolah haruslah dibentuk karakternya karena seperti yang kita ketahui bahwa sekolah itu merupakan salah satu wadah dalam pendidikan karakter.

Dalam merealisasikan pendidikan karakter di sekolah ini bisa dilakukan dengan berbagai macam hal. Bisa dalam hal kecil terlebih dahulu seperti belajar taat dengan peraturan sekolah, menegakan kedisiplinan, memberikan pengajaran tentang bertanggungjawab dengan cara memberikan pr dan para siswa diminta untuk mengerjakannya. Selain itu, dalam membentuk karakter di sekolah itu dapat melalui salah satu mata pelajaran, yaitu Pendidikan Kewarganegaraan. Mata pelajaran ini didalamnya itu banyak sekali pesan-pesan moral yang dapat diambil oleh para guru untuk membentuk karakter pada anak didiknya. Pendidikan Kewarganegaraan diberikan kepada peserta didik supaya dapat menjadikan mereka warga Negara yang baik. Pendidikan Kewarganegaraan mendukung fungsi dan tujuan dari pendidikan tinggi seperti yang tercantum dalam Undang-Undang Nomor 12 Tahun 2012. Pasal 4 disebutkan fungsi pendidikan tinggi yaitu: a) mengembangkan kemampuan dan membentuk watak dan peradaban bangsa yang bermartabat dalam rangka mencerdaskan kehidupan bangsa; b) mengembangkan Sivitas Akademika yang inovatif, responsif, kreatif, terampil, 
berdaya saing, dan kooperatif melalui pelaksanaan Tridharma; dan c) mengembangkan ilmu pengetahuan dan teknologi dengan memperhatikan danmenerapkan nilai Humaniora.

Bagaimana Pendidikan Kewarganegaraan itu dapat berperan dalam pembangunan dan pengembangan karakter dalam diri anak, tentu dapat terjawab jika adanya kontribusi yang diberikan Pendidikan Kewarganegaraan berhasil mengarahkan anak zaman sekarang untuk berpartisipasi dalam membangun karakter bangsa. Oleh karena itu, untuk langkah awal yang perlu dilakukan supaya membentuk karakter pada anak adalah melakukan pembelajaran Pendidikan Kewarganegeraan dengan baik dan se optimal mungkin.

Tujuan dari tulisan ini adalah mengetahui bagaimana peran Pendidikan Kewarganegeraan itu dalam pembentukan karakter pada anak. Selain itu, agar dapat mengetahui cara agar pembentukan karakter itu dapat berjalan secara optimal.

\section{METODE PENELITIAN}

Pada penelitian ini, metode yang digunakan adalah studi pustaka. Metode studi pustaka ini digunakan agar dapat mengetahui seberapa pentingnya peran Pendidikan Kewarganegaraan pada pembentukan karakter pada anak generasi milenial. Untuk memperoleh datanya itu dengan cara membaca dan mengambil sumber dari buku-buku yang sudah ada, jurnal, tesis, literatur, dan lain-lain yang sudah di interpetasikan agar tidak terjadi plagiat atau kesamaan dengan sumber tersebut dan juga yang pastinya harus berhubungan dengan masalah yang akan diteliti. Sumber data itu tak hanya bisa didapat dari penelitian secara langsung tetapi bisa didapat dari perpustakaan atau dokumen-dokumen lain dalam bentuk tulisan, baik dari jornal, buku maupun literatur yang lain. Langkah-langkah dari metode studi pustaka ini adalah mengumpulkan bahan-bahan penelitian. Karena dalam penelitian ini adalah penelitian kepustakaan, maka bahan yang dikumpulkan adalah berupa informasi yang bersumber dari buku-buku, jurnal, hasil laporan penelitian resmi maupun ilmiah dan literatur lain yang mendukung pada penelitian ini, membaca bahan kepustakaan. Dalam membaca bahan penelitian, pembaca harus membaca secara mendalam bahan bacaan yang memungkinkan akan menemukan ide-ide baru yang berkaitan dengan judul penelitian, membuat catatan penelitian. Kegiatan mencatat bahan penelitian boleh disebut tahap yang paling penting dan mungkin juga merupakan puncak yang paling sulit dari keseluruhan rangkaian karena pasti seluruh bahan yang telah dibaca harus ditarik sebuah kesimpulan dalam bentuk laporan penelitian, mengolah catatan penelitian. Semua bahan yang telah dibaca dan dipahami kemudian diolah atau dianalisis untuk mendapatkan kesimpulan yang disusun dalam bentuk laporan penelitian. 


\section{HASIL DAN PEMBAHASAN}

Pendidikan yang ada di Indonesia belum optimal terutama pada pembentukan karakter. Karakter ini merupakan suatu hal yang berhubungan dengan watak, tabiat, akhlak, atau kepribadian seseorang yang terbentuk dari hasil proses berbagai adab, akhlak, budi pekerti, dan etika yang diyakini dan digunakan sebagai landasan untuk cara pandang, bepikir, bersikap, dan bertindak. Pendidikan dan karakter itu tidak dapat dipisahkan karena satu sama lain itu saling berkaitan. Tanpa adanya pendidikan maka karakter tersebut tidak akan terbentuk.

Karakter pada anak dibangun agar nantinya si anak itu dapat bertindak sesuai aturan yang ada, maksudnya itu adalah tidak keluar dari aturan yang sudah dibuat. Dalam membangun karakter pada anak di sekolah itu dapat dilakukan dari hal kecil terlebih dahulu seperti, diajarkan tanggung jawab dalam mengerjakan tugas, belajar menaati peraturan sekolah yang ada, dan membangun sikap disiplin pada anak. Tak hanya itu, dalam membangun karakter anak itu dapat dilakukan melalui salah satu mata pelajaran, yaitu Pendidikan Kewarganegaraan.

Seperti yang kita ketahui, bahwa dalam Pendidikan Kewarganegaraan itu ada materi tentang nilai-nilai, norma dan peraturan hukum yang mengatur perilaku warga negara,dll. Dari materi-materi tersebut anak dapat dibentuk karakternya. Di materi nilai dan norma itu diajarkan tentang kesopanan, taat agama, hukum,dll. Pada materi itu dapat membantu anak untuk membentuk karakternya seperti contohnya, anak tersebut diajarkan untuk sopan pada orang tua, rajin untuk beribadah, dan taat akan pada aturan. Sedangkan, pada materi peraturan hukum yang mengatur perilaku warga negara itu diajarkan tentang peraturan apa saja yang ada di Indonesia ini yang dibutuhkan untuk mengatur perilaku warga negaranya. Pada materi itu juga dapat membantu anak untuk membentuk karakternya seperti contohnya, dalam hal bersikap dan bertindak di lingkungannya itu dapat sesuai dengan aturan yang ada dan sudah diatur dalam peraturan hukum. Hal itu dapat membantu anak agar belajar untuk tidak bersikap seenaknya kepada orang yang ada disekitarnya.

Jika anak sudah terpengaruh pada zaman milenial ini maka pembentukan karakter yang ada pada anak itu akan terganggu prosesnya, hal itu berdampak pada hasil pembentukan karakternya. Dalam membangun karakter pada anak juga tidak bisa semudah membalikan telapak tangan karena pasti banyak sekali rintangan yang harus dihadapi, salah satunya adalah pengaruh dari kebarat-baratan. Di zaman sekarang ini, sudah banyak anak yang berpakaian yang mengikuti trend masa kini yang tidak sesuai dengan nilai, norma, dan aturan yang ada di Indonesia. Anak zaman sekarang lebih pede untuk memakai pakaian mengikuti trend daripada untuk memakai pakaian yang sesuai aturan. Sehubungan dengan hal itu, anak zaman sekarang juga lebih suka untuk memakai barang-barang dari luar negeri daripada untuk memakai 
produk di negaranya sendiri yaitu Indonesia. Padahal seharusnya sebagai penerus bangsa ini, anak harus belajar untuk mencintai produk dalam negeri karena jika tidak, karater anak itu tidak akan sesuai dengan aturan yang ada. Anak harus diajarkan untuk lebih cinta terhadap produk lokal karena hal tersebut dapat membangun karakter cinta tanah air.

Untuk mengajarkan rukun dalam perbedaan itu bisa dengan cara diajarkan untuk menghargai temannya yang berbeda agama,suku,ras, dan budaya seperti contohnya itu, anak harus diajarkan untuk berteman itu harus dengan siapa saja tidak boleh milih-milih teman dengan melihat agama,suku, ras, dan budaya. Dapat juga dengan cara diajarkan untuk diajak bermain bersama atau bisa dengan diajak untuk bekerja sama dalam hal apapun misalnya piket bersama, berkelompok, dll. Hal itu dapat membangun karakter pada anak itu untuk selalu rukun dalam perbedaan dan tidak mengejek temannya yang berbeda agama, suku, ras, dan budaya.

Tak hanya itu, dalam pembelajaran Pendidikan Kewarganegaraan juga anak diajarkan tentang cinta terhadap lingkungan. Dalam hal ini dapat diajarkan dengan cara diajak untuk kerja bakti di sekolah dengan tujuan agar sekolah itu menjadi nyaman, bersih, sehat, dan asri. Kerja bakti harus dilakukan juga oleh gurunya, jadi tidak hanya menyuruh saja agar anak tersebut melihat bahwa gurunya juga ikut kerja bakti dan biasanya anak itu akan lebih terpengaruh serta anak itu akan mengikuti apa yang dilakukan oleh gurunya. Jika gurunya tidak ikut kerja bakti maka anak itu akan berfikir, "Ngapain kerja bakti? Cape-cape lebih baik istirahat, guru saya aja tidak ikut keja bakti , maka saya pun tidak akan melakukannya". Hal tersebut jangan sampai terjadi karena akan menganggu pembentukan karakternya. Oleh karena itu, guru harus menjadi suri tauladan untuk peserta didiknya dengan cara memberi contoh yang baik terhadap peserta didiknya. Guru tidak boleh sampai lengah dalam membentuk karakter anak dalam hal cinta lingkungan. Pembelajaran kerja bakti itu penting untuk anak karena agar nantinya anak akan terbiasa dan selalu menjaga lingkungan disekitarnya dan termasuk dirumahnya. Anak juga diajarkan untuk bersikap gotong royong, bekerja sama, saling tolong terhadap sesama temannya.

Pendidikan kewarganegaraan juga mengajarkan anak untuk taat dan patuh terhadap peraturan dan hukum yang ada di Indonesia. Untuk mengajarkannya bisa dari hal kecil terlebih dahulu misalnya, anak dilarang untuk mencuri atau mengambiil yang bukan haknya, maksudnya anak diajarkan untuk tidak mengambil barang dengan sembarangan milik temannya karena hal itu dapat membuat anak dilaporkan ke pihak berwajib. Anak pasti akan mengerti dan mengikuti apa yang dikatakan oleh gurunya karena biasanya anak itu akan lebih nurut dengan gurunya. Hal itu dapat membangun karakter anak yaitu taat akan 
peraturan yang ada dan bertindak sesuai aturan serta hukum di Indonesia.

Pendidikan Kewarganegaraan juga dapat berperan untuk menanamkan nilai-nilai agama pada generasi milenial. Karena, seperti yang kita ketahui bahwa dalam Pendidikan Kewarganegaraan itu terdapat nilai-nilai pancasila yang ada di sila ke-1, yaitu Ketuhanan Yang Maha Esa. Sila ke-1 tersebut mengajarkan kepada kita untuk selalu melaksanakan kewajiban kepada tuhan kita dan menjauhi larangan-Nya. Hal itu dapat berguna untuk kehidupan generasi milenial karena agar generasi milenial ini tidak salah dalam bersikap, bertingkah laku, berperilaku, dan bertindak agar sesuai dengan nilai-nilai religius.

Peran Pendidikan Kewarganegaraan ini juga ada di sila ke-2 pancasila yang berbunyi'Kemanusiaan Yang Adil dan Beradab”, yaitu Pendidikan Kewarganegaraan ini dijadikan sebagai acuan untuk generasi milenial agar tidak terlalu sering memainkan gadget, karena seperti yang kita ketahui bahwa generasi milenial ini tidak lepas dari yang namanya gadget. Hal itu akan membuat generasi milenial ini menjadi generasi yang individualis atau bisa dikatakan hanya mementingkan diri sendiri, tidak memperhatikan keadaan yang di sekitarnya. Dapat juga menyebabkan anak-anak ini akan terpengaruh terhadap pemberitaan hoax yang sering kali muncul yang akan memberi stigma yang negatif dan akan saling menyalahkan karena tidak tahu kebenarannya Pendidikan Kewarganegaraan ini diharapkan dapat menjadi acuan bagi generasi milenial untuk menyikapi sesuatu hal yang belum pasti kebenarannya dan juga dapat memahami persamaan harkat dan martabat diantara sesama manusia.

Dalam sila ke-3 yang berbunyi'Persatuan Indonesia" juga terdapat peran penting Pendidikan Kewarganegaraan, yaitu menumbuhkan sikap cinta tanah air, rela berkorban, demokrasi, rukun dalam perbedaan. Hal itu sangat penting ada dalam karakter anak juga karena agar anak tidak salah dalam bertindak juga dan dapat mencintai produk yang ada di Indonesia. Anak tidak akan mudah terpengaruh terhadap dunia kebarat-baratan. Kita tahu bahwa dalam dunia kebarat-baratan itu tidak sepenuhnya baik untuk pembentukan karakter anak karena ada beberapa hal yang tidak sesuai dengan nilai dan norma yang ada di Indonesia. Dapat menumbuhkan sikap demokrasi pada dalam diri anak dengan cara yang sederhana terlebih dahulu di sekolahnya seperti memilih voting untuk ketua kelas. Generasi milenial juga dapat lebih menghargai perbedaan yang ada di Indonesia dari mulai suku, agama, ras, dan budaya diantara teman-temannya dan orangorang yang ada di sekitarnya.

Pendidikan Kewarganegaraan juga dapat berperan untuk menjadikan generasi milenial ini belajar untuk menjadi pemimpin yang bijaksana, mementingkan kekeluargaan, mengambil keputusan dan tidak memaksakan kehendak diri sendiri. Sesuai 
dengan pengamalan nilai pancasila di sila ke4 yang berbunyi" Kerakyatan Yang Dipimpin Oleh Hikmat Kebijaksanaan Dalam Permusyawaratan Perwakilan”. Hal itu dapat menumbuhkan karakter pada generasi milenial yaitu menjadikan generasi milenial yang bijaksana, peduli sesama, dan tidak egois.

Di sila ke-5 yang berbunyi'Keadilan Sosial Bagi Seluruh Rakyat Indonesia" memuat juga nilai-nilai pancasila yang menjadikan peran pendidikan kewarganegaraan dalam pembentukan karakter pada generasi milenial yaitu adil terhadap orang lain, menghargai dan menghormati hak dan kewajiban setiap orang, dan mendukung setiap kemajuan pembangunan yang ada di Indonesia. Hal itu dapat menumbuhkan karakter pada generasi milenial yaitu adil, saling menghargai dan saling menghormati, dan lain-lain.

\section{KESIMPULAN}

Berdasarkan uraian diatas, dapat disimpulkan bahwa peran Pendidikan Kewarganegaraan dalam pembentukan karakter pada anak generasi milenial itu diperlukan karena dalam Pendidikan kewarganegaraan itu tak hanya diajarkan mengenai aturan dan hukum negara tetapi di Pendidikan Kewarganegaraan itu diajarkan juga tentang nilai dan norma, cara bersikap di masyarakat dan juga keluarganya. Pendidikan Kewarganegaraan bukanlah hanya sekedar mata pelajaran saja, tetapi Pendidikann Kewarganegaraaan ini digunakan sebagai tolak ukur dalam membentuk karakter pada anak. Di dunia pendidikan, Pendidikan Kewarganegaraan itu sangat penting dan tidak boleh sampai dihilangkan karena jika dihilangkan maka dalam proses pembentukan karakter itu tidak akan berjalan secara optimal. Pendidikan Kewarganegaraan itu mata pelajarang yang ada sejak SD sampai kita SMA, bahkan ada beberapa jurusan di perkuliahan yang ada mata kuliah Pendidikan Kewarganegaraan karena memang dibutuhkan untun beberapa jurusan di perkuliahan. Begitu pentingnya Pendidikan Kewarganegaraan itu bagi pendidikan Indonesia dan tidak bisa dipisahkan juga antara pembentukan karakter dan Pendidikan Kewarganegaraan. Dalam pembentukan karakter itu membutuhkan Pendidikan Kewarganegaraan karena tanpa Pendidikan Kewarganegaraan pembentukan karakter tidak akan berjalan secara optimal. Jika tidak ada yang membantu proses pembentukan karakter, maka bisa ada kemungkinan masalah tentang karakter pada anak akan terjadi, bahkan akan terjadi terus menerus dan tidak akan pernah selesai.

Pembentukan karakter pada anak harus lebih baik kedepannya dan tidak ada lagi masalah-masalah yang muncul tentang karakter pada anak. Perlu juga bantuan dari gurunya untuk membentuk karakter pada anak. Peran guru juga sangatlah penting bagi pembentukan karakter bagi anak. Tak hanya itu, peran orang tua juga sangatlah 
penting bagi pembentukan karakter anak karena keluarga adalah awal dari proses pembentukan karakter pada anak. Namun, tidak boleh juga untuk melupakan peran dari Pendidikan Kewarganegaraan juga dalam pembentukan karakter pada anak dan semoga Pendidikan Kewarganegaraan ini tetap ada dan diajarkan di sekolah-sekolah.

\section{DAFTAR PUSTAKA}

Humaidi. 2019. Revitalisasi Pendidikan Kewarganegaraan Bagi Generasi Milenial. Jurnal Ilmiah Keislaman dan Kemasyarakatan, 19(1), 140-146.

Izma, Tri \& Kesuma, Vira Yolanda. (2019). Peran Pendidikan Kewarganegaraan dalam Membangun Karakter Bangsa. Jurnal Wahana Didaktika, 17(1), 8492.

Nurjanah. (2018). Pembentukan Karakter Melalui Pembelajaran PKn Siswa SDN Peunaga Cut Ujong. Jurnal Ilmiah Pendidikan, 9(1), 77-89.

Akbal, Muhammad. 2016. Pendidikan Kewarganegaraan dalam Pembangunan Karakter Bangsa. Seminar Nasional, 485-493.

Jamaludin, Ujang dkk. 2017. Pendidikan Kewarganegaraan untuk Perguruan Tinggi. Buku Ajar Bersama BKSPTN Barat MK, 1-135.

Samrin. 2016. Pendidikan Karakter(Sebuah Pendekatan Nilai). Jurnal Kajian Ilmu Kependidikan, 9(1), 120-143.

Manurung, Lenni Hartati. 2019. Efektivitas Pembelajaran PKn terhadap Pendidikan Karakter Siswa dalam Mempersiapkan Generasi Millenial. Prosiding Seminar Nasional Fakultas
Ilmu Sosial Universitas Negeri Medan, Vol.3, 908-911.

Makmun, A. 2013. Nilai Nilai Moral dengan Kemungkinan Pengarahannya. AlMabsut: Jurnal Studi Islam dan Sosial, 7(2), 1-13.

Sukadi dkk. 2020. Representasi Pendidikan Kewarganegaraan pada Jenjang Pendidikan Tinggi Dilihat dari Perspektif Generasi Millenial. Jurnal Inspirasi Pendidikan, 10(2), 125-132.

Roza, Prima. 2020. Digital Citizenship: Menyiapkan Generasi Millenial Menjadi Warga Negara Demokratis di Abad Digital. Jurnal Sosioteknologi, 19(2), 190-202.

Hasanah, Uswatun. 2021. Implementasi Nilai-Nilai Pancasila di Kalangan Generasi Millenial untuk Membendung Diri dari Dampak Negatif Revolusi Industri 4.0. Jurnal Ilmiah Ilmu Pendidikan, 08(01), 5259.

Wagiono, Feri dkk. 2020. Pengembangan PKn Di Era Generasi Millenial Berbantuan M-Learning (Mobile Learning) Pada Gadget Pembelajaran Berbasis Cooperative Learning Bermuatan Karakter. Jurnal Ilmiah Pendidikan, 1(3), 63-72.

Hubbi, Unwanul dkk. 2020. Integrasi Pendidikan Karakter kedalam Pembelajaran Pendidikan Agama Islam dan Pendidikan Kewarganegaraan di Era Milenial. Jurnal Ilmu Sosial dan Pendidikan, 4(3), 228-239

Tuhuteru, Laros. 2017. Peran Pendidikan Kewarganegaraan dalam Peningkatan Pembentukan Karakter Bangsa di 
Tengah Arus Globalisasi. Prosiding Konferensi Nasional

Kewarganegaraan III, 302-305.

Anggarani, Novi. 2012. Pelaksanaan

Pembelajaran

Kewarganegaraan
Pendidikan Sebagai
Pendidikan Karakter di SMP SeKecamatan Parakan Kabupaten Manggung Tahun Ajaran 2011/2012. $S 1$ thesis, UNIVERSITAS NEGERI YOGYAKARTA. 